\title{
On-Chip DNA Methylation Analysis Using Osmium Complexation
}

\author{
Kaori Sugizaki, ${ }^{1}$ Tadashi Umemoto, ${ }^{1}$ and Akimitsu Okamoto ${ }^{1,2}$ \\ ${ }^{1}$ Nucleic Acid Chemistry Laboratory, RIKEN Advanced Science Institute, 2-1 Hirosawa, Wako, Saitama 351-0198, Japan \\ ${ }^{2}$ PRESTO, Japan Science and Technology Agency, 4-1-8 Honcho, Kawaguchi, Saitama 332-0012, Japan \\ Correspondence should be addressed to Akimitsu Okamoto, aki-okamoto@riken.jp
}

Received 28 February 2011; Accepted 1 April 2011

Academic Editor: Daisuke Miyoshi

Copyright () 2011 Kaori Sugizaki et al. This is an open access article distributed under the Creative Commons Attribution License, which permits unrestricted use, distribution, and reproduction in any medium, provided the original work is properly cited.

The development of a reaction for detecting the presence/absence of one methyl group in a long DNA strand is a chemically and biologically challenging research subject. A newly designed chemical assay on a chip for the typing of DNA methylation has been developed. A methylation-detection probe fixed at the bottom of microwells was crosslinked with methylated DNA mediated by osmium complexation and contributes to selective amplification of methylated DNA.

\section{Introduction}

Gene expression is well regulated by the epigenetic modification of DNA and histone tails independent of their primary sequences. In particular, cytosine methylation, in which the C5 position of the cytosine base is methylated enzymatically, plays a crucial role in the regulation of chromatin stability, gene regulation, parental imprinting, and $\mathrm{X}$-chromosome inactivation in females [1-4]. Therefore, detection of cytosine methylation is very important, and much effort has gone into developing a simple reaction for 5-methylcytosine $\left({ }^{\mathrm{m}} \mathrm{C}\right)$ detection.

For the evaluation of the methylation status of genes, several conventional methods have so far been used, such as a cleavage assay with methylation-insensitive restriction enzymes [5-7], hydrolysis and sequencing with a bisulfite salt $[8-10]$, and immunofluorescence with anti-5methylcytosine antibody $[11,12]$. Although the conventional methods have many merits, there are many disadvantages, and methylation detection assays must be further improved through another approach. The existence of a more rapid and selective chemical reaction capable of distinguishing between methylcytosine and unmethylated cytosine on a chip has promise as a good method for efficiently analyzing the status of cytosine methylation at a specific site in a gene.

The sequence-selective DNA methylation-detection probe, ICON (interstrand complexes formed by osmium and nucleic acids), may be effective for the development of an on-chip analysis of DNA methylation [13-15]. In the presence of osmium oxidants and a bipyridine ligand, 5methylcytosine forms a stable osmium-centered complex, in contrast to unmethylated cytosine (Figure 1) [16-19]. ICON probes form a crosslink with a specific 5-methylcytosine in the probe-hybridizing DNA mediated by osmium-centered complex formation. This function will be effective for the capture of methylated DNA on a chip for sequence-selective methylation analysis.

In this paper, development of an on-chip analyzing method for typing of DNA methylation at a specific cytosine is reported. ICON probes fixed to the bottom of microwells assisted the on-chip detection of the methylation status of a specific cytosine in the target DNA.

\section{Materials and Methods}

2.1. Synthesis of an ICON Probe. Artificial DNA was synthesized by the conventional phosphoramidite method using an Applied Biosystems 392 DNA/RNA synthesizer or an NTS H-6 DNA/RNA synthesizer. The phosphoramidite form of bipyridine-modified adenine (B) was prepared according to the synthetic protocol described in a previous paper [13]. The $5^{\prime}$-amino end was attached using the phosphoramidite of $5^{\prime}$-aminomodifier C12 (Glen 


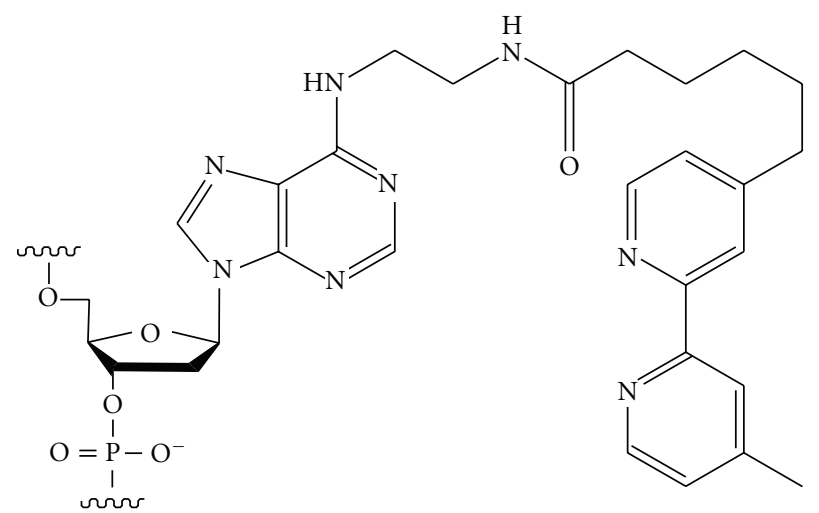

B

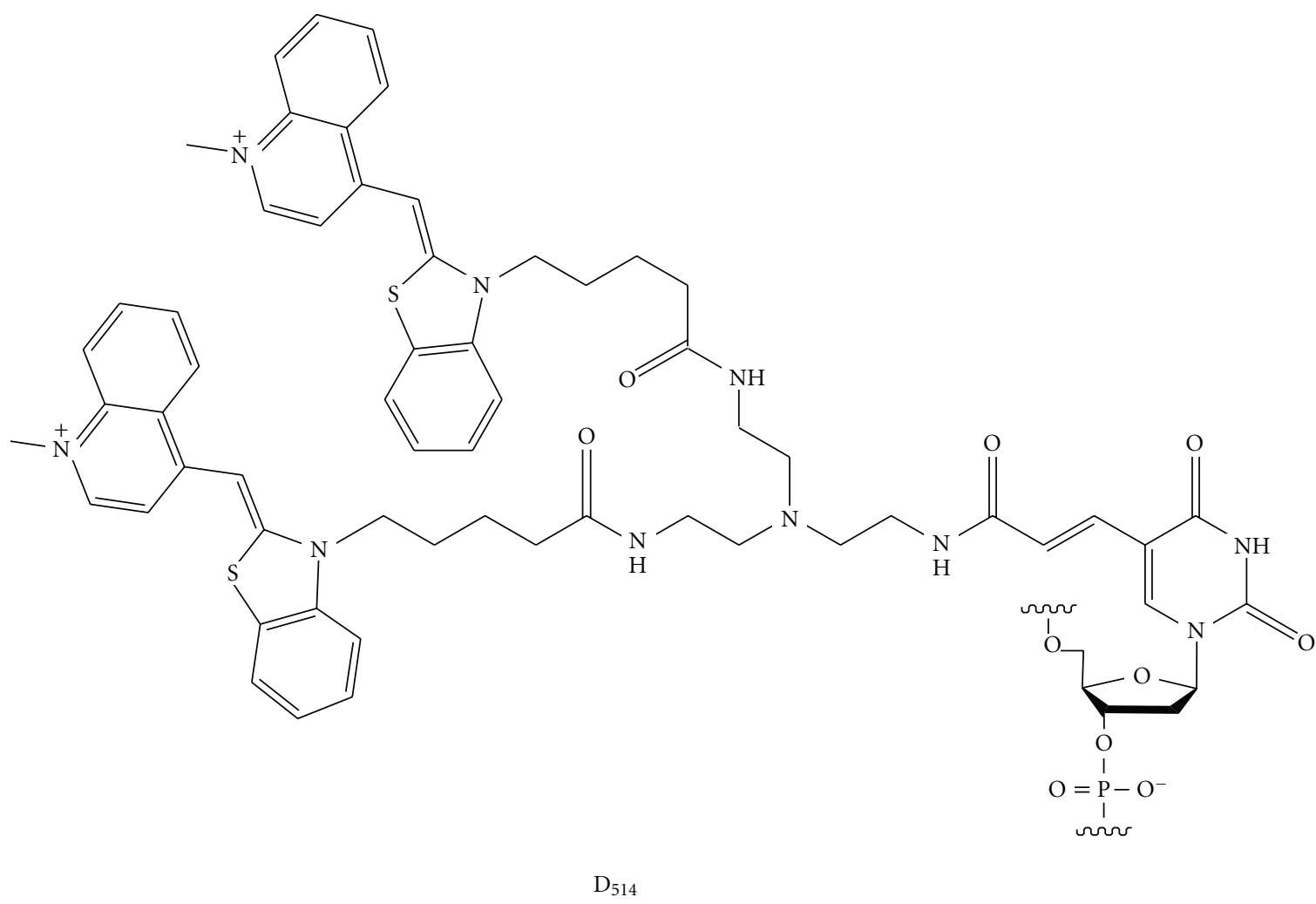

FIGURE 1: Structures of the "B" nucleotide of the ICON probe for 5-methylcytosine selective crosslink formation and the " $\mathrm{D}_{514}$ " nucleotide of the Exciton primer for real-time PCR monitoring.

Research (http://www.glenresearch.com/index.php)). Synthesized DNA was purified by reverse phase HPLC on a 5-ODS-H column $(10 \mathrm{~mm} \times 150 \mathrm{~mm}$, elution with a solvent mixture of $0.1 \mathrm{M}$ triethylammonium acetate (TEAA), $\mathrm{pH} 7.0$, linear gradient over $30 \mathrm{~min}$ from $5 \%$ to $20 \%$ acetonitrile at a flow rate of $3.0 \mathrm{~mL} / \mathrm{min})$. The DNA strand was characterized by MALDI-TOF MS. $5^{\prime}-\mathrm{NH}_{2}-\left(\mathrm{CH}_{2}\right)_{12}$ CCCCСCСССССACAACCTCCBTCATGTGCTGAA-3' ([M $+\mathrm{H}]^{+}$, calcd. $\mathrm{C}_{343} \mathrm{H}_{452} \mathrm{~N}_{118} \mathrm{O}_{198} \mathrm{P}_{33}, 10418.0$, found 10416.0).

2.2. Preparation of Chips. A $100 \mu \mathrm{L}$ solution of synthetic DNA $(100 \mathrm{nM})$ in TE buffer $(\mathrm{pH} 7.0)$ or deionized water in the presence of $10 \mathrm{mM}$ 1-ethyl-3-(3-dimethylaminopropyl)carbodiimide, and $10 \mathrm{mM} 1$-methylimidazole was put into each well of NucleoLink strips (Nalge Nunc (http://www.nalgenunc.com/)). After incubation at $50^{\circ} \mathrm{C}$ for $5 \mathrm{~h}$, the reaction mixture was removed from the well, and the well was rinsed three times with a solution of $100 \mathrm{mM}$ Tris$\mathrm{HCl}$ ( $\mathrm{pH}$ 7.5), $150 \mathrm{mM}$ sodium chloride, and $0.1 \%$ Tween 20 , and then three times with deionized water.

2.3. Osmium Treatment and DNA Amplification. The target DNA sequence p53( $\left.\mathrm{N}^{1}-\mathrm{N}^{2}\right)$ was 5'-TGT GCA GCT GTG G GTT GAT T CGA CAC CCC C GCC CGG CAC C CGC 
GTC CGC G CCA TGG CCA T CTA CAA GCA G TCA CAG CAC A TGA N ${ }^{1}$ GG AGG T TGT GAG G N² G C TGC CCC CAC C-3' $\left(\mathrm{N}^{1}, \mathrm{~N}^{2}=\mathrm{C}\right.$ or $\left.{ }^{\mathrm{m}} \mathrm{C}\right)$. A $25 \mu \mathrm{L}$ solution of DNA $(8 \mathrm{nM})$ in $50 \mathrm{mM}$ Tris- $\mathrm{HCl}$ buffer (pH 7.7), $0.5 \mathrm{mM}$ EDTA, and $1 \mathrm{M}$ sodium chloride was added to each probe-attached well at $0^{\circ} \mathrm{C}$. The reaction mixture was incubated at $0^{\circ} \mathrm{C}$ for $5 \mathrm{~min}$, and then the solution was removed from the wells. A $25 \mu \mathrm{L}$ solution of $5 \mathrm{mM}$ potassium osmate(VI) and $100 \mathrm{mM}$ potassium hexacyanoferrate(III) in $50 \mathrm{mM}$ Tris- $\mathrm{HCl}$ buffer ( $\mathrm{pH}$ 7.7), $0.5 \mathrm{mM}$ EDTA, and $1 \mathrm{M}$ sodium chloride was incubated at $0{ }^{\circ} \mathrm{C}$ for $5 \mathrm{~min}$ or at $25^{\circ} \mathrm{C}$ for $10 \mathrm{~min}$. The wells were rinsed seven times with $0.4 \mathrm{M}$ sodium hydroxide, $0.25 \%$ Tween $20(130 \mu \mathrm{L} /$ well). After further rinsing with deionized water twice, the wells were coated with $10 \mathrm{mg} / \mathrm{mL}$ BSA in $100 \mathrm{mM}$ Tris- $\mathrm{HCl}(\mathrm{pH} 7.5), 150 \mathrm{mM}$ sodium chloride, and $0.1 \%$ Tween 20 . The process of PCR amplification was performed in a reaction solution of $1 \mathrm{U} \mathrm{TaKaRa} \mathrm{Ex} \mathrm{Taq}$ HS, $10 \times$ buffer, $2.5 \mathrm{mM}$ dNTP mix, and $1 \mu \mathrm{M}$ primer mix (Forward, 5' -AGCTGD ${ }_{514}$ GGGTTGATTC-3' for the Exciton primer method, 5'-TGTGCAGCTGTGGGTTGATTC$3^{\prime}$ for the SYBR Green I method; reverse, 5' ACTGCTTGTAGATGGCCATG-3'; $\mathrm{D}_{514}$ in an Exciton primer is a hybridization-sensitive fluorescent nucleotide (Figure 1)). In the case of using the stain method with SYBR Green I fluorescence for monitoring the amplification, SYBR Green I dye was also added to the reaction mixture in advance. Amplifications were performed in microwells as follows: after heating at $95^{\circ} \mathrm{C}$ for $60 \mathrm{~s}, 35$ cycles of denaturation at $95^{\circ} \mathrm{C}$ for $5 \mathrm{~s}$, annealing with fluorescence monitoring at $52^{\circ} \mathrm{C}$ for $20 \mathrm{~s}$, and extension at $72^{\circ} \mathrm{C}$ for $20 \mathrm{~s}$ on the Corbett Rotor-Gene, the amplification process was monitored by the fluorescence of $\mathrm{D}_{514}$ or SYBR Green I through an SYBR Green I ( $470 \mathrm{~nm} / 510 \mathrm{~nm})$ filter.

\section{Results and Discussion}

3.1. Preparation of Chips and Osmium Complexation. For the on-chip study, we adopted a NucleoLink strip, because it is a microwell strip in which the amino-modified ICON probe can be attached to well bottoms with covalent bonds. The target DNA was a fragment of the human p53 gene exon 5 including mutation hotspots at $\mathrm{CpG}$ dinucleotides [20]. The sequence of the ICON probe was designed to form a crosslink with one of the methylated cytosines in the target DNA. The ICON probe was modified with an amino end for attaching to the plate and an alkyl linker and a poly $\mathrm{C}$ sequence for introducing enough distance between the probe and the plate. This ICON probe was synthesized by the conventional phosphoramidite method by using a DNA autosynthesizer. The phosphoramidite form of bipyridine-modified adenine (B) was prepared according to the synthetic protocol described in a previous paper [13]. Synthetic DNA was fixed to the bottom of each well of NucleoLink strips in the presence of 1-ethyl-3-(3dimethylaminopropyl)carbodiimide and 1-methylimidazole (Figure 2). The wells were rinsed and used for the next reaction.
Oxidative osmium complexation using ICON probes is a rapid and mild reaction for detection of methylated DNA, and it is not accompanied with nonspecific strand damage, in contrast to conventional bisulfite methods. Therefore, this reaction would be effective for on-chip analysis of DNA methylation. The target DNA was put into the wells and hybridized with the ICON probes fixed in the wells. The DNA samples in the wells were incubated at $0^{\circ} \mathrm{C}$ for $5 \mathrm{~min}$ then at $25^{\circ} \mathrm{C}$ for $5 \mathrm{~min}$ in the presence of $5 \mathrm{mM}$ potassium osmate(VI) and $100 \mathrm{mM}$ potassium hexacyanoferrate(III) in $50 \mathrm{mM}$ Tris- $\mathrm{HCl}$ buffer (pH 7.7), $0.5 \mathrm{mM}$ EDTA, and $1 \mathrm{M}$ sodium chloride. After reaction, the wells were rinsed with $4 \mathrm{M}$ sodium hydroxide and then coated with BSA.

3.2. Exciton Primer and Real-Time PCR Monitoring. The fixed DNA was detected using PCR amplification of a part of the crosslinking DNA strand. The PCR primers were designed for the region without ICON binding. For one of the primers, a hybridization-sensitive fluorescent DNA was used, containing a fluorescent nucleotide $\mathrm{D}_{514}$ (Figure 1) [21-24]. This fluorescent DNA shows very weak fluorescence in the unhybridized state, whereas it shows strong fluorescence after hybridization with the complementary nucleic acids. This fluorescence switching is controlled by an intramolecular excitonic interaction between dyes tethered to the DNA. This fluorescent DNA is useful as a PCR primer. This DNA shows weak fluorescence emission, whereas the PCR mixture emits strong fluorescence after PCR amplification. This system has been applied to the detection of single nucleotide polymorphisms in genome DNA samples [25]. We tested this "Exciton primer" for onchip PCR. The process of PCR amplification was performed in a reaction solution of TaKaRa Ex Taq HS polymerase in the presence of a mixture of dNTP and primer mix. Amplifications were performed in microwells and the change in the fluorescence intensity monitored using a real-time PCR system. In the experiment for $\mathrm{p} 53\left({ }^{\mathrm{m}} \mathrm{C}-\mathrm{C}\right)$ and $\mathrm{p} 53(\mathrm{C}-$ $\mathrm{C}$ ), the methylation of the target cytosine was determined from the increase in the fluorescence signal associated with the exponential growth of the PCR product. Amplification of the $\mathrm{p} 53\left({ }^{\mathrm{m}} \mathrm{C}-\mathrm{C}\right)$ started first, and then the amplification of p53 $(\mathrm{C}-\mathrm{C}$ ) started several cycles later (Figure 3 ). Washingout of uncrosslinked sample DNA brought about this lag in the starting point of amplification. The amplification curve observed for p53(C-C) almost overlapped that for the osmium-untreated p53( $\left.{ }^{\mathrm{m}} \mathrm{C}-\mathrm{C}\right)$, suggesting that the amplification curve for unmethylated DNA is due to amplification of the DNA nonspecifically adsorbing to the well surface. On-chip capture of methylated DNA by the ICON probe at the methylation site made possible the sequence specific detection of methylation through PCR amplification.

3.3. Sequence-Specific Amplification. A prototype for ICONbased on-chip methylation analysis makes possible sequencespecific amplification. We prepared four DNA strands with different methylation sites, p53(C-C), p53 $\left({ }^{\mathrm{m}} \mathrm{C}-\mathrm{C}\right)$, p53(C$\left.{ }^{\mathrm{m}} \mathrm{C}\right)$, and $\mathrm{p} 53\left({ }^{\mathrm{m}} \mathrm{C}-{ }^{\mathrm{m}} \mathrm{C}\right)$. The sample DNA was added to the wells, in which the ICON probe targeting only the ${ }^{\mathrm{m}} \mathrm{C}$ of 


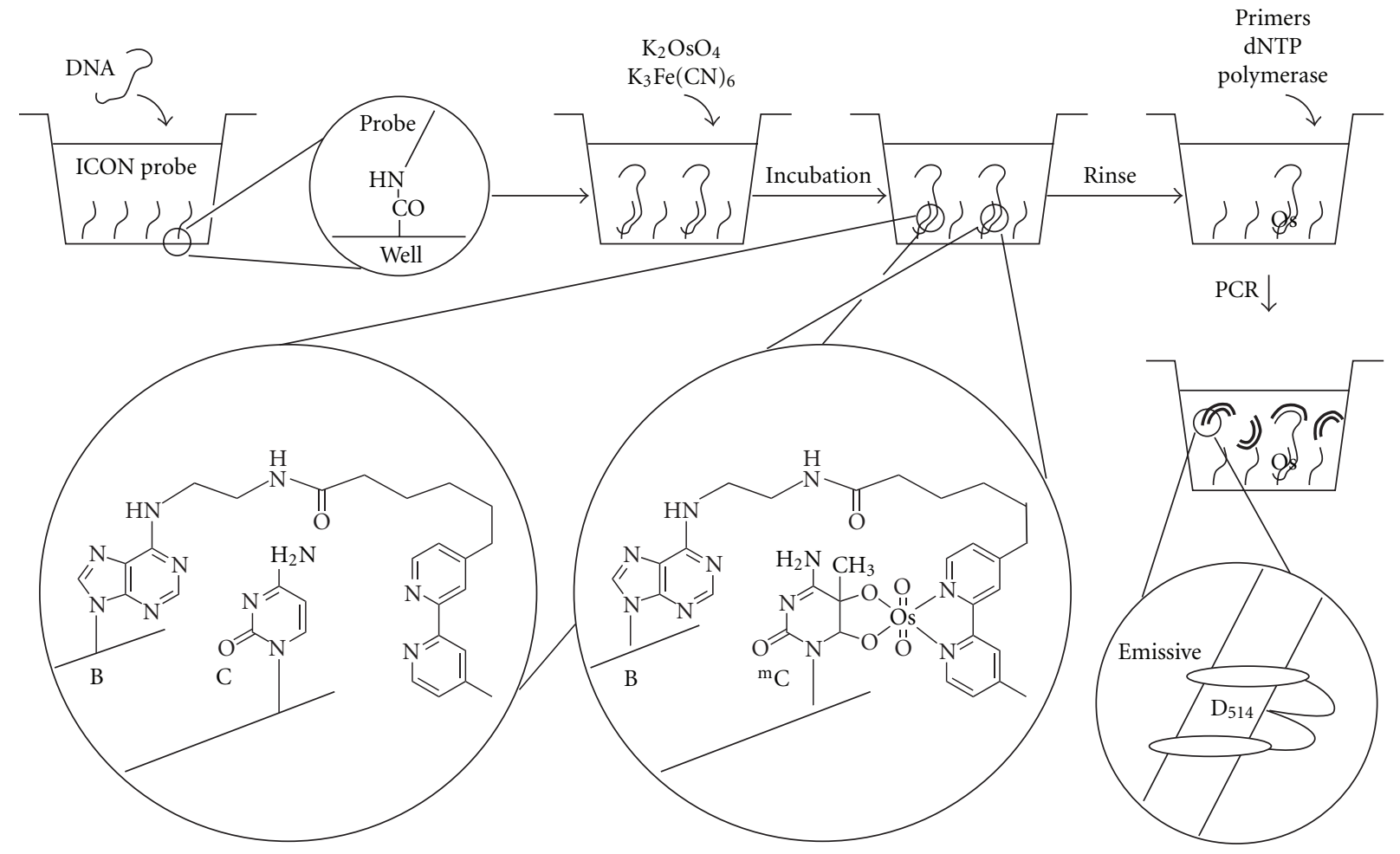

FIgURE 2: Schematic illustration of on-chip analysis of methylated DNA.

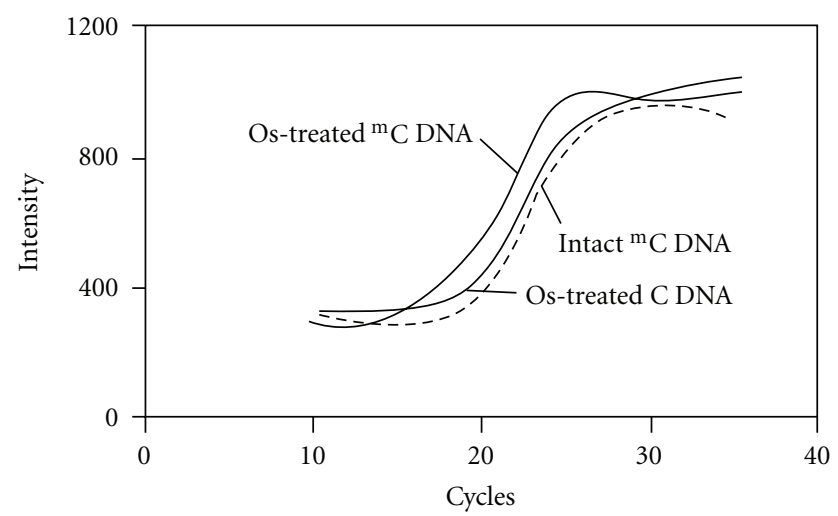

Figure 3: Profile of real-time PCR for p53( $\left.{ }^{\mathrm{m}} \mathrm{C}-\mathrm{C}\right)$ and $\mathrm{p} 53(\mathrm{C}-\mathrm{C})$ with/without osmium oxidation.

the sample DNA 5' side was fixed. After osmium treatment and BSA coating, the crosslinked DNA was amplified by PCR in the presence of unlabeled primers and SYBR Green I. After 15 cycles of the amplification reaction, the fluorescence intensity of SYBR Green I was quantified on a microplate reader (Figure 4). The wells containing p $53\left({ }^{\mathrm{m}} \mathrm{C}-\right.$ C) and $\mathrm{p} 53\left({ }^{\mathrm{m}} \mathrm{C}-{ }^{\mathrm{m}} \mathrm{C}\right)$ exhibited higher fluorescence intensities compared with those from wells containing p53(CC) and $\mathrm{p} 53\left(\mathrm{C}-{ }^{\mathrm{m}} \mathrm{C}\right)$. The ICON probe fixed on the well bottom distinguished $5^{\prime}-{ }^{\mathrm{m}} \mathrm{C}$ from $3^{\prime}-{ }^{\mathrm{m}} \mathrm{C}$ and detected only methylation of $5^{\prime}-\mathrm{C}$ regardless of methylation of $3^{\prime}$-C.

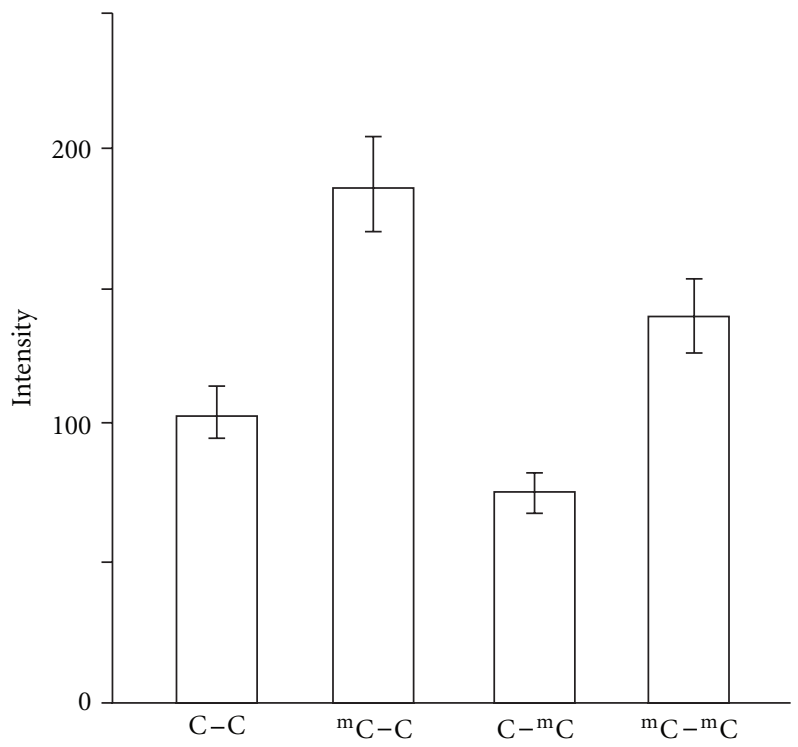

FIGURE 4: Sequence-specific detection of DNA methylation at $\mathrm{N}^{1}$ in p53 $\left(\mathrm{N}^{1}-\mathrm{N}^{2}\right)$ using an ICON probe.

\section{Conclusions}

We have described a new, high-value aspect of on-chip methylation analysis through osmium-DNA complexation. An ICON probe fixed onto a microwell formed a crosslink with the target 5-methylcytosine and assisted the detection 
using PCR amplification. The crosslink was sequenceselective and completely independent of the other methylation site. Although there remain further aspects to be examined toward realizing an easier-to-use methylation analysis, such as optimization of PCR conditions suitable for ICON, this on-chip assay supported by the chemical basis could be an important component of the next generation of high-throughput methylation analyses.

\section{Acknowledgment}

The authors thank Dr. Takehiro Suzuki (RIKEN) for the MALDI-TOF mass spectrometry.

\section{References}

[1] P. L. Jones and A. P. Wolffe, "Relationships between chromatin organization and DNA methylation in determining gene expression," Seminars in Cancer Biology, vol. 9, no. 5, pp. 339$347,1999$.

[2] P. H. Tate and A. P. Bird, "Effects of DNA methylation on DNA-binding proteins and gene expression," Current Opinion in Genetics and Development, vol. 3, no. 2, pp. 226-231, 1993.

[3] V. Colot and J. L. Rossignol, "Eukaryotic DNA methylation as an evolutionary device," BioEssays, vol. 21, no. 5, pp. 402-411, 1999.

[4] R. Feil and S. Khosla, "Genomic imprinting in mammals: an interplay between chromatin and DNA methylation?" Trends in Genetics, vol. 15, no. 11, pp. 431-435, 1999.

[5] M. F. Kane, M. Loda, G. M. Gaida et al., "Methylation of the hMLH1 promoter correlates with lack of expression of hMLH1 in sporadic colon tumors and mismatch repairdefective human tumor cell lines," Cancer Research, vol. 57, no. 5, pp. 808-811, 1997.

[6] A. Okamoto, K. Tanabe, and I. Saito, "Site-specific discrimination of cytosine and 5-methylcytosine in duplex DNA by peptide nucleic acids (PNA)," Journal of the American Chemical Society, vol. 124, no. 35, pp. 10262-10263, 2002.

[7] A. Okamoto, "Synthesis of highly functional nucleic acids and their application to DNA technology," Bulletin of the Chemical Society of Japan, vol. 78, no. 12, pp. 2083-2097, 2005.

[8] H. Hayatsu, Y. Wataya, K. Kai, and S. Iida, "Reaction of sodium bisulfite with uracil, cytosine, and their derivatives," Biochemistry, vol. 9, no. 14, pp. 2858-2866, 1970.

[9] M. Frommer, L. E. McDonald, D. S. Millar et al., "A genomic sequencing protocol that yields a positive display of 5- methylcytosine residues in individual DNA strands," Proceedings of the National Academy of Sciences of the United States of America, vol. 89, no. 5, pp. 1827-1831, 1992.

[10] J. G. Herman, J. R. Graff, S. Myöhänen, B. D. Nelkin, and S. B. Baylin, "Methylation-specific PCR: a novel PCR assay for methylation status of CpG islands," Proceedings of the National Academy of Sciences of the United States of America, vol. 93, no. 18, pp. 9821-9826, 1996.

[11] M. Mizugaki, K. Itoh, T. Yamaguchi et al., "Preparation of a monoclonal antibody specific for 5-methyl-2' -deoxycytidine and its application for the detection of DNA methylation levels in human peripheral blood cells," Biological and Pharmaceutical Bulletin, vol. 19, no. 12, pp. 1537-1540, 1996.

[12] C. Montpellier, C. A. Bourgeois, N. Kokalj-Vokac et al., "Detection of methylcytosine-rich heterochromatin on banded chromosomes: application to cells with various status of DNA methylation," Cancer Genetics and Cytogenetics, vol. 78, no. 1, pp. 87-93, 1994.

[13] K. Tanaka, K. Tainaka, T. Umemoto, A. Nomura, and A. Okamoto, "An osmium-DNA interstrand complex: application to facile DNA methylation analysis," Journal of the American Chemical Society, vol. 129, no. 46, pp. 14511-14517, 2007.

[14] A. Nomura, K. Tainaka, and A. Okamoto, "Osmium complexation of mismatched DNA: effect of the bases adjacent to mismatched 5-methylcytosine," Bioconjugate Chemistry, vol. 20, no. 3, pp. 603-607, 2009.

[15] A. Okamoto, "Chemical approach toward efficient DNA methylation analysis," Organic and Biomolecular Chemistry, vol. 7, no. 1, pp. 21-26, 2009.

[16] A. Okamoto, K. Tainaka, and T. Kamei, "Sequence-selective osmium oxidation of DNA: efficient distinction between 5-methylcytosine and cytosine," Organic and Biomolecular Chemistry, vol. 4, no. 9, pp. 1638-1640, 2006.

[17] T. Umemoto and A. Okamoto, "Synthesis and characterization of the 5-methyl-2' -deoxycytidine glycol-dioxoosmiumbipyridine ternary complex in DNA," Organic and Biomolecular Chemistry, vol. 6, no. 2, pp. 269-271, 2008.

[18] K. Tanaka, K. Tainaka, and A. Okamoto, "Methylcytosineselective fluorescence quenching by osmium complexation," Bioorganic and Medicinal Chemistry, vol. 15, no. 4, pp. 16151621, 2007.

[19] K. Tanaka, K. Tainaka, T. Kamei, and A. Okamoto, "Direct labeling of 5-methylcytosine and its applications," Journal of the American Chemical Society, vol. 129, no. 17, pp. 5612-5620, 2007.

[20] S. Tornaletti and G. P. Pfeifer, "Complete and tissueindependent methylation of CpG sites in the p53 gene: implications for mutations in human cancers," Oncogene, vol. 10, no. 8, pp. 1493-1499, 1995.

[21] S. Ikeda and A. Okamoto, "Hybridization-sensitive on-off DNA probe: application of the exciton coupling effect to effective fluorescence quenching," Chemistry-An Asian Journal, vol. 3, no. 6, pp. 958-968, 2008.

[22] A. Okamoto, "Excitonic interaction: another photophysical process for fluorescence-controlled nucleic acid sensing," Chemical Record, vol. 10, no. 3, pp. 188-196, 2010.

[23] T. Kubota, S. Ikeda, and A. Okamoto, "Doubly thiazole orange-labeled DNA for live cell RNA imaging," Bulletin of the Chemical Society of Japan, vol. 82, no. 1, pp. 110-117, 2009.

[24] S. Ikeda, T. Kubota, M. Yuki, and A. Okamoto, "Excitoncontrolled hybridization-sensitive fluorescent probes: multicolor detection of nucleic acids," Angewandte Chemie International Edition, vol. 48, no. 35, pp. 6480-6484, 2009.

[25] A. Lezhava, T. Ishidao, Y. Ishizu et al., "Exciton primermediated SNP detection in SmartAmp2 reactions," Human Mutation, vol. 31, no. 2, pp. 208-217, 2010. 

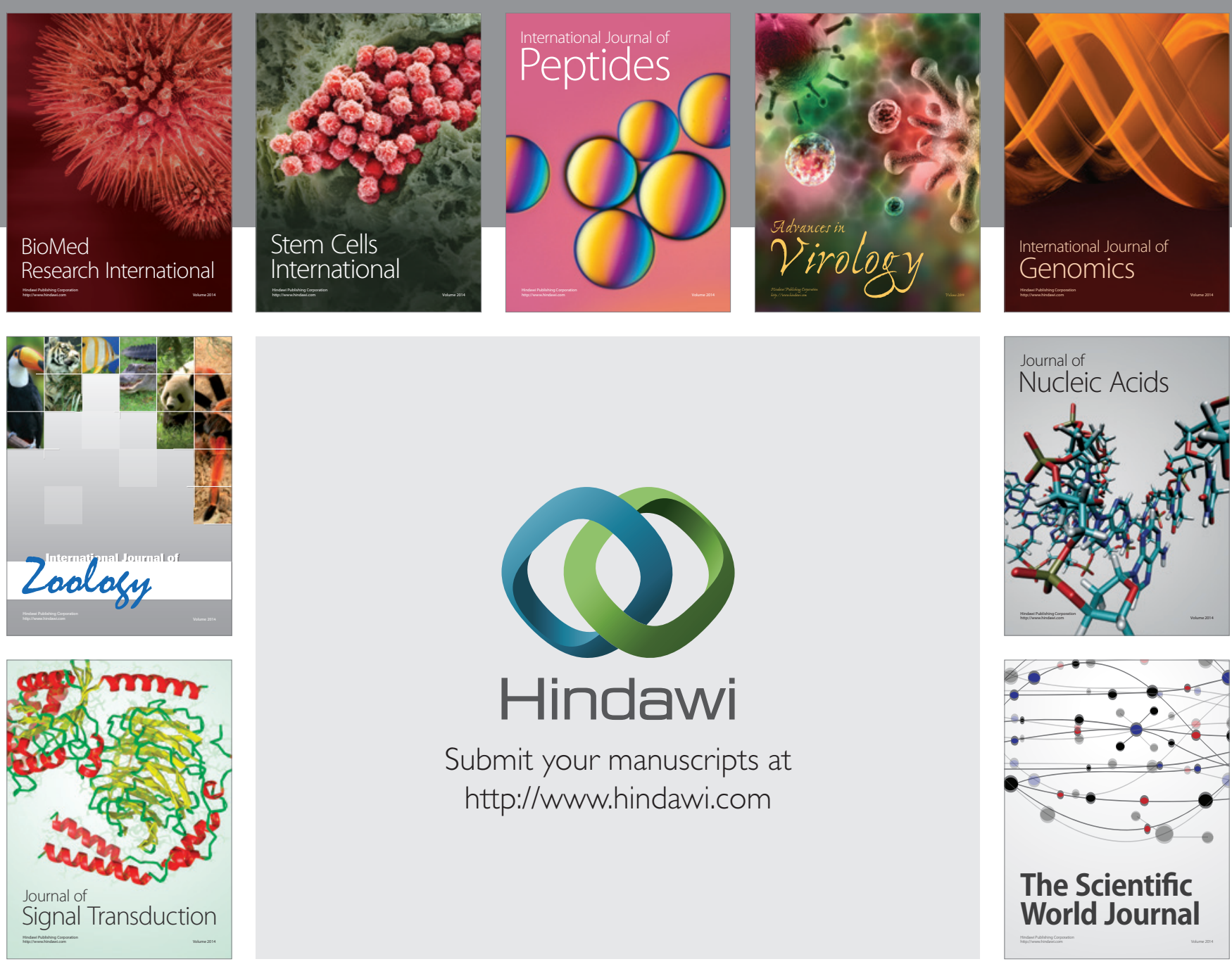

Submit your manuscripts at

http://www.hindawi.com
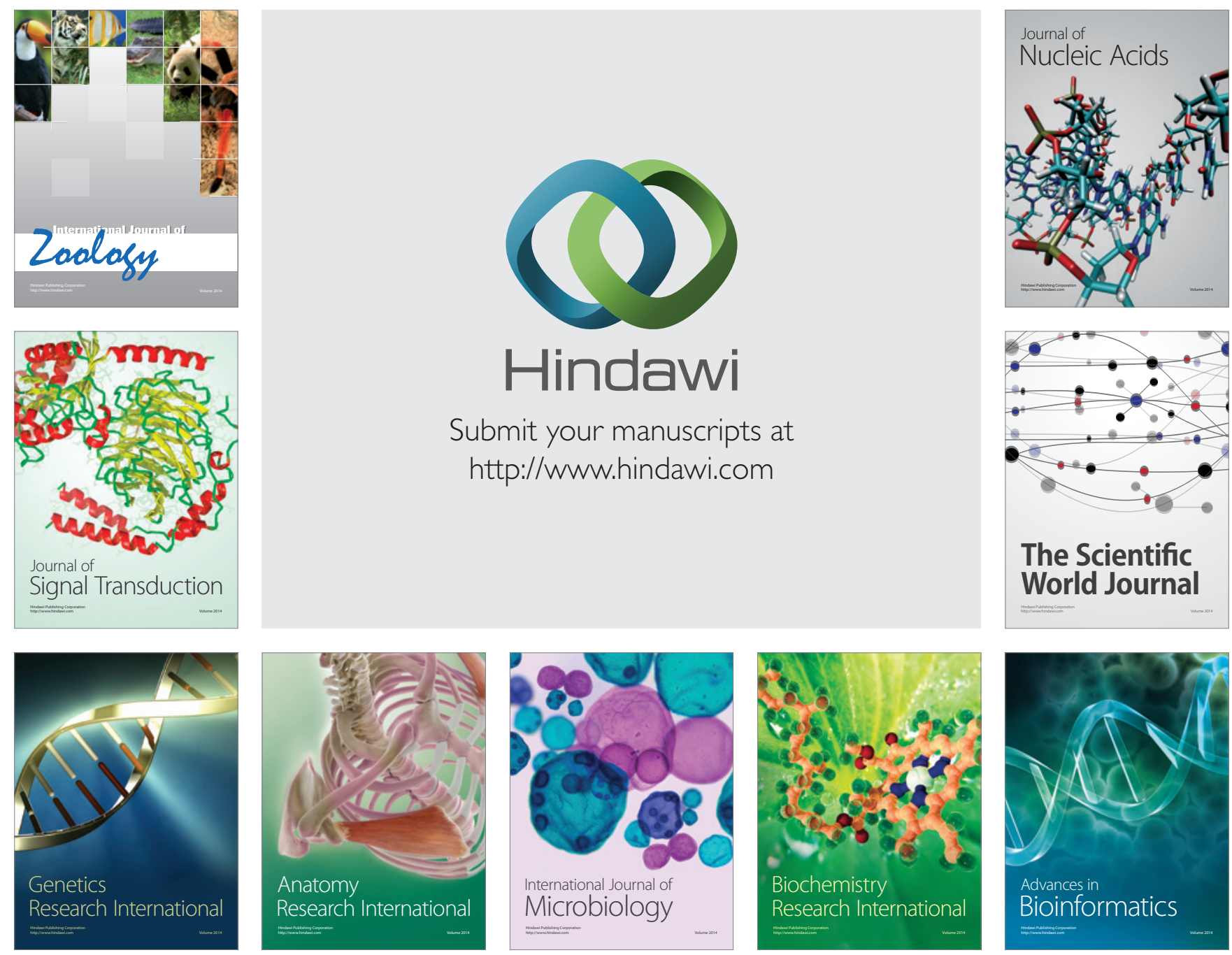

The Scientific World Journal
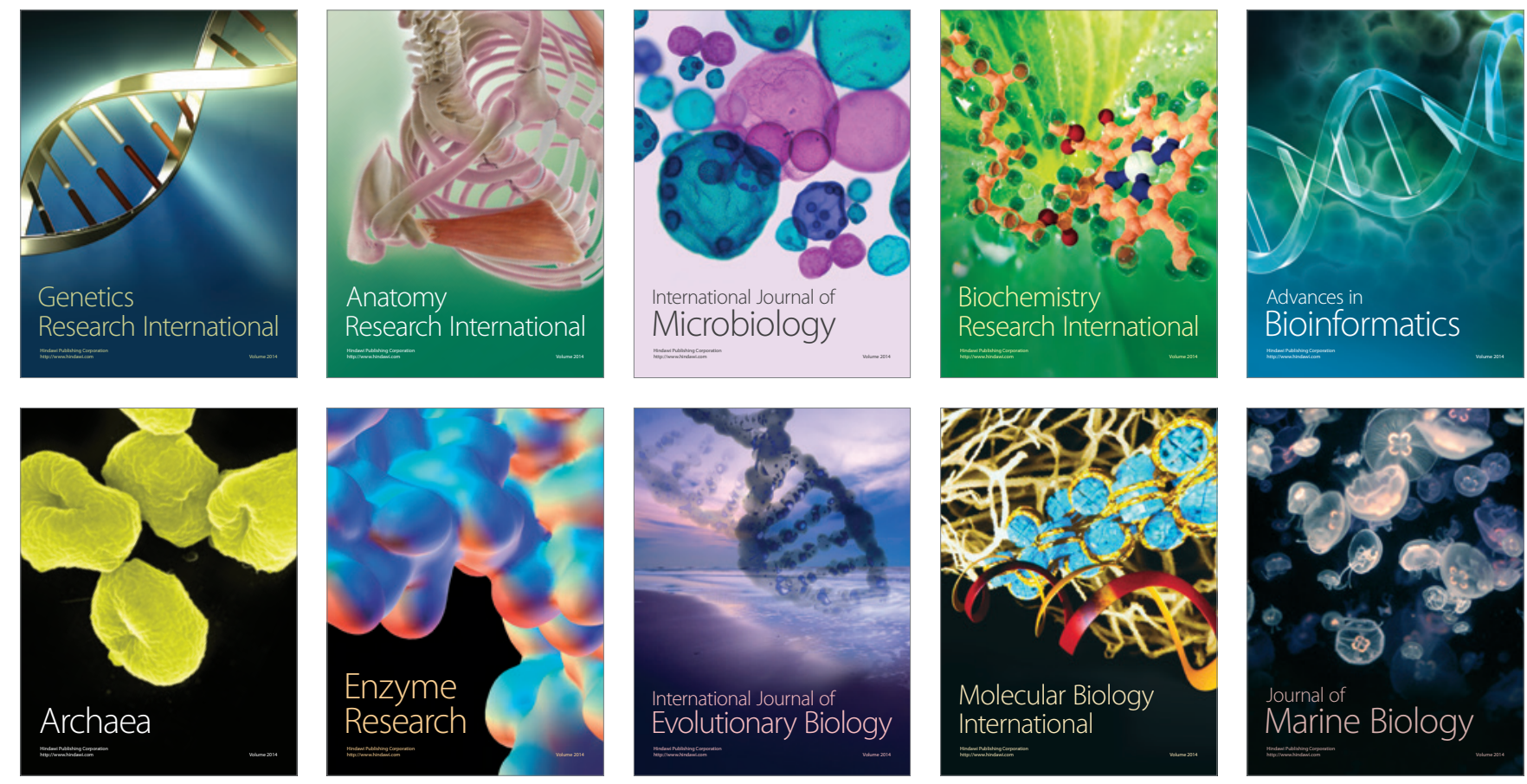